\title{
A Comment on "Walras' law in the context of pre-analytic visions: a note" by Arne Heise
}

\author{
Heise, A. 2016. "Walras' Law in the context of re-analytic visions: a note". Discussion Papers \\ Hamburg, Center for Economic and Sociological Studies (CESS/ZÖSS). \\ Contact information at EDIRC, pp. 1-12. \\ Narciso TÚÑEZ AREA \\ narcisotunez@gmail.com
}

Received: 09/11/2016

Accepted: 11/11/2016

Resumen: [De Heise, A. 2016]

La ley de Walras es central a la formación de la teoría económica. Para la economía ortodoxa, es un medio de comprobar el rigor y la consistencia de la construcción modelo; para los economistas heterodoxos, la refutación de la ley de Walras es clave para comprender la contribución revolucionaria de Keynes a un nuevo paradigma económico. El objetivo de esta nota de investigación es plantear la posibilidad de una refutación de la ley de Walras e investigar sus condiciones previas. Se argumentará que esto sólo puede alcanzarse con una visión alternativa preanalítica de la economía monetaria tal y como John Maynard Keynes previó.

Palabras clave: ley de Walras, axioma de sustitución bruta, restricciones presupuestarias, problema de la realización, desequilibrio compensatorio

\begin{abstract}
From Heise, A. 2016]
Walras' law is central to the formation of economic theory. For mainstream economics, it is a device for testing rigorousness and consistency of model-building; for heterodox economists, the refutation of Walras' law is the key to understanding Keynes' revolutionary contribution to a new economic paradigm. The purpose of this short research note is to elaborate on the possibility of a refutation of Walras' law and to inquire into its preconditions. It will be argued that this can only be achieved on the basis of an alternative pre-analytic vision of a genuine monetary economy as foreshadowed by John Maynard Keynes.
\end{abstract}

Keywords: Walras' Law, Gross Substitution Axiom, budget constraints, realization problem, compensatory disequilibrium

JEL Classification: B12, B13, B22, E5, D50

In a recent paper Heise has questioned the validity of Walras' Law and its applicability to a genuine monetary economy. He makes references to my paper in the IJHET, Túñez Area $(2015):^{1}$

commodities do not buy commodities' and hence there is always the necessity to transform commodity value into money value to purchase other commodities $[\ldots]$ the excess supply of commodities in the goods market might fail to be matched by an excess demand for money. Hence, Walras' Law does not hold and disequilibrium might not be compensatory...

Túñez Area (2015, p. 111)

Money is, therefore, the only medium of exchange to buy commodities. Hence, money buys commodities but commodities do not buy commodities. Therefore, the Gross Substitution Theorem does not apply which is a more realistic abstraction of monetary market economies.

Túñez Area (2015, p. 106)

\footnotetext{
${ }^{1}$ Túñez Area, Narciso. 2015. The Validity of Walras' Law in a Monetary Exchange Economy: Money, Prices and the Integration of Monetary and Value Theory, Iberian Journal of the History of Economic Thought, vol. II (2), pp. 101-114.
} 
Although I agree with him about the importance of getting rid of Walras' Law to reinstate Keynes' contribution to economic theory, he makes a few assertions that I intend to clarify.

1. "The (in)famous 'hydraulic Keynesianism' of the ISLM scheme seemed to contradict Walras' law".

The IS-LM model does not, in general, contradict the validity of Walras' Law. What it is assumed (wrongly) is that the labour market always remains in equilibrium. ${ }^{2 \text { " }}$ At first sight, then, there would seem to be no place for the operation of Walras' Law. One way out of this difficulty -there may well be others- is to assume it away by attributing to workers a completely passive behaviour pattern according to which they adjust the amount of labour they plan to supply to the amount employers demand at the going wage rate. Hence, by definition, "equilibrium" always exists in the labour market (Patinkin, 1958, p. 314). However, by doing so, involuntary unemployment is also assumed away.

2. "Palley (1998) has shown [...] that every demand for labour as much as every supply of labour corresponds to a supply of and demand for money income in a monetary economy, a situation of unemployment (i.e. excess supply of labour) matches an excess demand for money income, re-instating Walras' law again."

Although I did not think necessary at the time, in retrospect, I think I should have made this clear in my paper about the validity of Walras' Law. I do not disagree that Walras' Law holds true assuming that the gross substitutions theorem holds, i.e. that any commodities can be substituted for money and be used therefore to buy another commodity. Even so, Palley's statement is wrong as the supply of labour would correspond to a demand for money as much as to a demand for commodities. Asserting otherwise is probably due to confusion about the nature of the demand for money, i.e. a stock not a flow variable. Hence, all realized decisions to buy commodities generates flows of the medium of exchange but not demands for it. In any case, defining supply of labour as a demand for money can be hardly reconciled with Classical or Keynesian views. And I am not asserting that unemployed would not have planned expenditures just as firms have planned investment, I am only stressing the fact that this should already be included in the demand for money equation however it is defined. Individuals' preference for liquidity imposes a restriction on trading that Walras' Law does not take into account and neither did Palley for that matter.

3. "is it really money's function as medium of exchange (as in $\alpha$ ) which distinguishes a barter or exchange economy from a monetary economy? 2) It is really the introduction of a medium of exchange which explains the peculiar properties (as in $\beta$ ) as Túñez Area $(2015$, p. 106) asserts".

In the mentioned paper I am analysing a monetary exchange economy where money only functions as a medium of exchange, not a modern monetary economy where money is also a store of value. Hence, the singular property of money as the only mean of exchange is a difference but not the only difference that separates modern monetary economies from a barter exchange economy. The intention in starting from the simplest monetary exchange model is precisely to separate both roles of money to show that Walras' Law is violated even when there are no credit markets but also to create a theoretical framework -based on a more realistic abstraction of modern economies- from which we can start building more complex models.

4. "The zero (or negligible) elasticity of substitution of money, on the other hand, is the indication of the peculiar status of the most liquid asset -money- in an economy based on nominal obligations instead of exchange activities".

The practically zero elasticity of substitution of money is a condition that must hold even when credit markets do not exist and hence cannot be an indication of the difference between models with or without credit markets.

5. "The resulting budgetary constraint allows for equilibrium on the money, credit, and commodity markets once expectations are fulfilled and is compatible with partial, compensating disequilibrium..."

\footnotetext{
${ }^{2}$ Patinkin, D. 1958. Liquidity preference and Loanable Funds: Stock and Flow analysis, Economica, vol. XXV.
} 
The budget constraint resulting from a model with credit markets will not be compatible with compensating disequilibrium either. However, this will be assessed in a forthcoming paper.

6. "However, this accountancy truism is not to be confused with Walras' law simply because in a genuine monetary economy, a labour market does not exist as an operating supply and demand mechanism adjusting according to real rewards (i.e. real wages; see e.g. Lavoie, 2014, p. 275; Seccareccia, 1991)"

The validity of Walras' Law is independent of whether supply and demand for labour adjust to real rewards or not and independent of whether there is disequilibrium or not. Furthermore, a labour supply function can be constructed to depend on nominal wages -within limits- instead of real wages; and still an excess supply of labour might exist that matches a compensatory disequilibrium somewhere else in the system according to Walras' Law That's to say, the adjustment process is independent with the validity of the law.

On one hand, for Lavoie the labour supply is totally elastic at the current nominal wage which means that labour adjusts its supply to match the level of the demand. But it also means that individuals, along the supply of labour curve, are indifferent between working more or leisure and hence they are optimizing their decisions according to consumer choice theory. However, either Lavoie's vertical line only represents trade at current nominal wages and hence it does not represent optimal behaviour, or involuntary unemployment is impossible by definition. I do not think Keynes would agree with either of these statements.

On the other hand, the labour demand in Lavoie's work is different from Keynes' labour demand. For Lavoie, aggregate supply does not come from the maximization problem of firms solabour demand does not reflect conditions in the maximization of profits. However, I believe the reconciliation is possible as Keynes' $Z$ function can be obtained from Lavoie's $\left(\pi^{S}\right)$ function and effective demand from the intersection of $\left(\pi^{S}\right)$ and $\left(\pi^{d}\right)$.

7. "...yet there is no operational mechanism (i.e. no market) based on a re-adjustment of real remuneration rates that would automatically close a potential gap between job offers from companies and employment offers from labourers as implied by Walras' law"

Here, again, there is confusion between Walras' Law and the dynamic of adjustment towards equilibrium. The validity of the former does not imply the latter and vice versa. Whatever mechanism of adjustment is assumed to exist in the labour market and independently of whether it is based on real remuneration rates or not, the validity of Walras' Law might still hold if disequilibrium is compensatory. Nevertheless, further from the rigid exogenous definition of nominal wages, Keynes' main point was that even if nominal wages are totally flexible, a decrease in its value, due to the forces of supply and demand or not, will not bring about a decrease in its real value as real wage depends on factors that affect all other market and not just the labour market. In Túñez Area (2014) it is exposed how this can be portrayed in the (w, N) plane. $^{3}$

8. "Any refutation of Walras' law has to rely on a different pre-analytic vision based on creditor-debtor-relationships as a basic constituent."

As stated before this is false as the introduction of credit markets as in Patinkin $(1965)^{4}$ does not imply the invalidity of the law and the exclusion of credit markets does not guarantee its validity either as it is exposed in Túñez Area (2015). The insertion of money as a medium of exchange introduces uncertainty about the outcome of the exchange process even if it takes no time. This type of uncertainty is different from the one that money, as a store of value, brings about which cannot be analysed until credit markets are introduced.

9. "Walras' law epitomizes a theoretical understanding of economic activity which does not allow for a 'general glut' of commodities and 'involuntary unemployment' as equilibrium outcomes."

\footnotetext{
${ }^{3}$ Túñez Area, N. 2014. The demand for labour: A Post-Keynesian appraisal, Iberian Journal of the History of Economic Thought. vol. 1 (2), pp. 38-50.

${ }^{4}$ Patinkin, D. 1965. Money, Interest and Prices.New York, Harper \& Row and John Weatherhill
} 
Walras' Law is compatible with involuntary unemployment in disequilibrium. However, as it has been exposed above what it is not compatible with involuntary unemployment is assuming a horizontal supply curve of labour which is what Patinkin and Lavoie, among others, have done. 